\title{
Desain Kewilayahan dan Posisi Middle Power dalam Strategi Hedging Kazakhstan terhadap Rusia dan Tiongkok
}

\author{
Muhamad Anugrah Pratama \\ Universitas Airlangga
}

\begin{abstract}
ABSTRAK
Kazakhstan dihadapkan pada kontestasi Rusia dan Tiongkok yang berkompetisi untuk memperoleh pengaruh dan meningkatkan keterlibatan mereka di wilayah Asia Tengah sejak tahun 1990-an. Dalam menghadapi situasi tersebut, Kazakhstan menjalankan kebijakan luar negeri hedging yang termasuk dalam tajuk 'multi-vector policy'. Hal ini memiliki keunikan karena Kazakhstan secara geografis merupakan negara landlocked dan memiliki hubungan historis yang dekat dengan Rusia. Pertanyaan yang diajukan dalam tulisan ini adalah mengapa Kazakhstan melakukan kebijakan luar negeri hedging dalam melakukan hubungan dengan Rusia dan Tiongkok di Asia Tengah? Tulisan ini lantas menggunakan perspektif geopolitik kewilayahan dan posisi middle power negara untuk mencari jawaban atas pertanyaan tersebut. Hasil analisis penulis menunjukkan bahwa kebijakan hedging yang dilakukan oleh Kazakhstan dengan Rusia dan Tiongkok dipengaruhi oleh adanya perubahan desain kewilayahan Kazakhstan yang akhirnya memengaruhi perspektif elit sehingga memilih menjalankan kebijakan mencirikan middle power, yaitu hedging.
\end{abstract}

Kata Kunci: Kazakhstan, Kebijakan Luar Negeri, Hedging, Desain Kewilayahan, Middle Power

Kazakhstan is faced with the contestation between Russia and China who are competing to gain influence and increase their involvement in Central Asia region since 1990s. In facing the situation, Kazakhstan use hedging in its foreign policy, which can be seen in its 'multi-vector policy'. Kazakhstan's policy towards the 2 countries proved unique and consistent considering its status as a landlocked country and its historical dependent and consistent relation with Russia as an ally, Kazakhstan chose to adopt contradictory and 'balanced' foreign policy toward the 2 countries. Hence, this paper attempt to question why Kazakhstan adopted hedging foreign policy in its relation with Russia and China in Central Asia. In answering this question, this paper utilized geopolitical and territorial design perspective and a country's middle power position. The author found that Kazakhstan's hedging foreign policy toward China and Russia was influencedby the change in Kazakhstan's territorial design which in turn influenced elite perspective on Kazakhstan's security and adopted policies.

Keywords: Kazakhstan, Foreign Policy, Hedging, Territorial Design, Middle Power 


\section{Pendahuluan}

Wilayah Asia Tengah yang berada dalam himpitan Rusia di utara dan Tiongkok di Selatan terdiri dari lima negara yang berada dalam posisi landlocked atau terhimpit daratan dengan tidak adanya akses ke lautan membuat negara-negara tersebut memiliki kerugian strategis dan ekonomis dibandingkan negara-negara yang memiliki akses ke laut. Wilayah Asia Tengah juga mengandung banyak kekayaan alam dan hamparan yang luas, serta berada di 'tengah-tengah' dunia yang pada awal tahun 1900-an disebut oleh McKinder sebagai Heartland dan orang-orang yang dapat menguasai wilayah sekitar Asia Tengah dapat menguasai dunia. Tetapi, Kazakhstan memiliki permasalahan dengan dua negara tetangga. Kazakhstan memiliki kekhawatiran akan ancaman dari utara, yaitu Rusia yang memiliki permasalahan perbatasan, konsentrasi populasi Slav di wilayah utara Kazakhstan, diskursus Rusia mengenai Kazakhstan sebagai ekstensi atau backyard dari Rusia, dan kekhawatiran akan adanya ambisi neoimperial Rusia (Ayazbekov 2014, 34). Selain itu, Kazakhstan juga memiliki kecanggungan dengan Tiongkok yang menganggap bahwa Kazakhstan merupakan salah satu titik yang dapat menimbulkan konflik etnis dan gerakan separatis di daerah Xinjiang, adanya ingatan buruk mengenai konflik Sino-Soviet, percobaan nuklir di Lob Nor, dan sebagai tempat imigrasi ilegal bagi masyarakat Han Tiongkok (Ayazbekov 2014, 34).

Sementara itu, setelah kemerdekaan, ternyata kehadiran Tiongkok di Asia Tengah-yang secara tradisional merupakan sphere of influence Rusia-justru membawa elemen persatuan bagi kedua negara tersebut melalui mekanisme multilateral seperti Shanghai Cooperation Organization (SCO), maupun bilateral (Weitz 2006, 58). Rusia dan Tiongkok juga memiliki worldview yang hampir serupa karena sama-sama-sama khawatir akan persebaran ideologiideologi seperti demokrasi Barat dan fundamentalisme Islam (Weitz 2006, 159). Dalam hal ini, Kazakhstan menjadi menarik untuk diteliti, karena selama ini dengan adanya kedekatan historis dengan Rusia, kekayaan sumber daya alam yang melimpah, dan posisi negara landlocked yang terisolasi, mengapa Kazakhstan memutuskan untuk melakukan hedging dan menjalankan kebijakan luar negeri 'multivektor'. Tidak seperti negara-negara Asia Tengah yang lainnya yang rata-rata masih merupakan negara berkembang, Kazakhstan memiliki keunikan dalam desain kewilayahannya serta pemilihan kebijakan yang mencirikan middle power setelah kemerdekaannya. 


\section{Kebijakan Luar Negeri Hedging Kazakhstan}

Aspek pertama yang akan dibahas mengenai strategi hedging Kazakhstan terhadap Tiongkok dan Rusia adalah aspek economic pragmatism (Cheng-Chwee 2008, 167). Aspek pragmatism terletak pada poros tengah dan termasuk dalam sisi return-maximizing option dalam konsepsi hedging menurut Kuik Cheng-Chwee (2008). Pragmatisme ekonomi terjadi saat suatu negara berusaha memaksimalkan perdagangan dan investasi dengan negara berkekuatan besar walaupun terjadi masalah di antara mereka. Jika dioperasionalisasikan, suatu negara yang memiliki kebijakan ini cenderung mengembangkan jaringan sosial-ekonomi dengan membentuk koordinasi birokratik untuk menjaga hubungan tersebut (Cheng-Chwee 2008, 167).

Kebijakan Kazkhstan terhadap Tiongkok sarat dengan pragmatisme ekonomi. Kazakhstan menjadi salah satu mitra dagang dan politik terpenting yang dimiliki Tiongkok di Asia Tengah, walaupun pada saat itu, keterlibatan ekonomi Tiongkok lebih berfokus pada Asia Tenggara daripada Asia Tengah, tetapi volume perdagangan Tiongkokdengan Kazakhstan hanya selisih sedikit. Data pada tahun 2016 menunjukkan bahwa Tiongkok merupakan destinasi ekspor terbesar Kazakhstan dengan jumlah 4.3 miliar USD, disusul Rusia dengan 3.75 miliar USD. Sementara itu, impor terbesar Kazakhstan yang terbesar berasal dari Rusia dengan jumlah 9.2 miliar USD, disusul oleh Tiongkok dengan 4.23 miliar USD (OEC t.t.).

Data diatas menunjukkan adanya neraca perdagangan yang seimbangantara Kazakhstan dengan Tiongkok. Sementara itu, neracaperdagangan antara Kazakhstan dengan Rusia cenderung membawa ketidakseimbangan bagi Kazakhstan. Aspek yang lain dari perdagangan adalah investasi. Jika dilihat melalui persentase arus masuk kotor FDI (foreign direct investment) ke Kazakhstan pada tahun 2017, Belanda menempati nomor 1 dengan 30\% dari seluruh FDI yang masuk ke Kazakhstan, disusul oleh Amerika Serikat dengan persentase sebesar $17 \%$, lalu Inggris menempati urutan ketiga, sedangkan Tiongkok menempati posisi keempat dengan jumlah FDI dibawah 20.000 juta USD.

Aspek selanjutnya adalah binding-engagement. Engagement merupakan kebijakan pada saat suatu negara berusaha membangun dan menjaga kontak dengan negara berkekuatan besar dengan tujuan untuk membentuk sarana komunikasi, meningkatkan 'suara', dan mempengaruhi pilihan kebijakan negara berkekuatan besar. 
Sementara itu, binding merupakan usaha suatu negara untuk menginstitusionalisasikan hubungannya dengan suatu negara melalui hubungan diplomatik yang rutin. Sedangkan, bindingengagement terjadi saat suatu negara mengintegrasikan negara berkekuatan besar dalam tatanan yang mereka dirikan untuk menetralkan kecenderungan perilaku revisionis (Cheng-Chwee 2008, 168).

Perilaku binding-engagement Kazakhstan dan negara-negara Asia Tengah lainnya terhadap Tiongkok terjadi dalam Shanghai Cooperation Organization (SCO). SCO menjadi salah satu organisasi regional yang diprioritaskan oleh Kazakhstan karena salah satu fokusnya adalah untuk mengembangkan keamanan regional Asia Tengah dan SCO dapat menyediakan Kazakhstan dan negara-negara Asia Tengah lainnya kesempatan untuk membatasi kehadiran Tiongkok yang mendominasi di Asia Tengah secara multilateral. Seperti contoh, pada saat adanya pertemuan $12^{\text {th }}$ Heads of State Summit yang diadakan di Beijing pada tanggal 6-7 Juni 2012, negara-negara tersebut tidak membahas masalahmasalah yang mendesak dan dapat menghambat suasana kooperasi dan harmoni, seperti masalah-masalah perbatasan dan ketahanan suplai air, tetapi lebih membahas ke masalah keamanan dan ekonomi (Peyrouse 2012, 1). Hal ini berusaha diatasi oleh Kazakhstan dengan ajakan Nursultan Nazarbayev supaya SCO membahas dan menyelesaikan masalah perbatasan di antara negara-negara Asia Tengah (Kamalova 2014).

Selain itu, Kazakhstan menganggap perlunya menambahkan masalah defisit air dalam Concept of Development of the Shanghai Cooperation Organization sampai pada tahun 2025 dan Kazakhstan mengusulkan dibentuknya Water Committee yang dapat menjadi mekanisme praktikal (Kazpravda 2015). Perilaku Kazakhstan ini berbeda dengan perilaku Tiongkok yang tidak ingin menyinggung masalah-masalah sensitif dan juga memperlihatkan SCO sebagai alat tawar dalam menghadapi masalah dengan Tiongkok. Kazakhstan dan Rusia juga memiliki kedekatan dalam hubungan multilateral dengan keterlibatan mereka di beberapa organisasi, seperti Commonwealth of Independent States (CIS), Eurasian Economic Union (EAEU atau EEU), Collective Security Treaty (CSTO), dan Customs Union (Sultangaliyeva 2016, 33).

Aspek selanjutnya adalah limited-bandwagoning. Limitedbandwagoning (LB) berbeda dari pure bandwagoning (PB). LB lebih mengarah kepada kemitraan politik yang meliputi koordinasi 
kebijakan dalam isu-isu terpilih dan secara sukarela memihak kepada mitra yang lebih besar. Selain itu, bedanya PB dengan LB adalah dalam LB tidak selalu zero-sum dan suatu negara dapat menjalin hubungan dengan beberapa negara berkekuatan besar secara bersamaan. Tetapi, dalam LB, negara-negara kecil tidak sertamerta menggantungkan semua nasibnya pada negara berkekuatan besar, tetapi juga menjaga jarak dan tidak menjadi over-dependent (Cheng-Chwee 2008, 168-169).

sPada tahun 1992, Tiongkok mengimbau supaya negara-negara Asia Tengah mendukung 'One China Policy' yang hanya mengakui Tiongkok sebagai pemerintahan yang memiliki legitimasi dan mengakui Taiwan sebagai bagian yang tidak terpisahkan dari Tiongkok dan tidak menjalin hubungan diplomatis dengan Taiwan (Shodnghanga t.t. 99). Selain itu, hal ini juga berlaku kepada Xinjiang dan Tibet yang sedang berusaha memerdekakan diri dari Tiongkok. Pada tahun 2002, Kazakhstan dan Tiongkok menandatangani Good Neighbor Treaty of Friendship and Cooperation (Weitz 2008, 103) kemudian dilanjut pada tahun 2013 dengan Joint Declaration on Further Deepening Comprehensive Strategic Partnership yang memiliki poin-poin untuk memperkuat hubungan dan kepercayaan bersama dari sisi ekonomi, kerjasama mengenai sungai lintas batas, dan keamanan (China International Water Law Programme t.t.).

Kazakhstan juga memiliki beberapa koordinasi kebijakan dan kemitraan politik dengan Rusia yang ditunjukkan melalui kesamaan pandangan mengenai integrasi Eurasia dalam kebijakan luar negeri mereka dan terus memperbarui perjanjian politik, salah satunya pada 15 Oktober 2015 melalui perjanjian On GoodNeighborliness and Alliance into the $21^{\text {st }}$ Century (Sultangaliyeva 2016, 33). Selain itu, dalam koordinasi kebijakan, pada tahun 2011, Rusia secara resmi mendukung Kazakhstan sebagai kandidat chairman OSCE dan Kazakhstan juga melakukan hal yang sama dengan menahan diri untuk menyalahkan Rusia pada voting PBB dalam krisis Krimea (Sultangaliyeva 2016, 33)

Aspek selanjutnya adalah dominance denial. Kebijakan ini ditujukan untuk mencegah dan menanggulangi negara berkekuatan besar dalam yang terlalu predominan dalam hubungannya dengan negaranegara regional. Hal ini terlihat dalam hubungan Kazakhstan dengan Tiongkok di dalam SCO. Dalam hal ekonomi, Kazakhstan tidak selalu memihak Tiongkok dan terkadang lebih setuju dengan Rusia. Hal ini terlihat pada tahun 2002, pada saat Tiongkok mem- 
beri penawaran untuk mengubah SCO menjadi zona perdagangan bebas. Dihadapkan dengan penawaran tersebut, Kazakhstan merasa khawatir dan berargumen bahwa zona perdagangan bebas hanya dapat bekerja jika negara-negara yang terlibat memiliki kesamaan tingkat ekonomi. Sementara itu, Kazakhstan menawarkan opsi lain, yaitu mengembangkan hubungan ekonomi hanya dalamsektor tertentu saja, seperti dalam pembangunan koridor transportasi dan transit hidrokarbon antara anggota-anggota SCO, sehingga tidak meningkatkan kemungkinan akan adanya penguasaan ekonomi oleh Tiongkok dan menjadikan Kazakhstan sebagai protektorat ekonomi Tiongkok (Peyrouse 2008).

Kazakhstan sejak awal sudah mengambil posisi netral serta pragmatis yang ditunjukkan salah satunya melalui pidato Nazarbayev pada tahun 1997 dengan menyatakan bahwa Kazakhstan menghindari 'mentalitas blok atau sekutu' dan menganggap tindakan semacam itu sebagai sesuatu yang 'tidak dapat ditoleransi' (Ambrosio dan Lange 2014, 551). Kasus yang menunjukkan pragmatisme Kazakhstan dan keengganannya untuk menuruti Rusia terlihat pada saat adanya konflik antara Georgia dengan Rusia pada tahun 2008. Kazakhstan yang memiliki kepentingan geopolitik dan ekonomi di Kaukasus, terutama Georgia yang pada awalnya mendukung respons agresif Rusia terhadap Georgia, seiring waktu menolak untuk mendukung kebijakan Rusia dengan mengakui kemerdekaan Ossetia Selatan. Selain itu, dalam pertemuan SCO, Kazakhstan mengimbau negaranegara untuk menjaga integritas wilayah mereka (Hanks 2009, 266).

\section{Kerangka Teori dan Pemikiran}

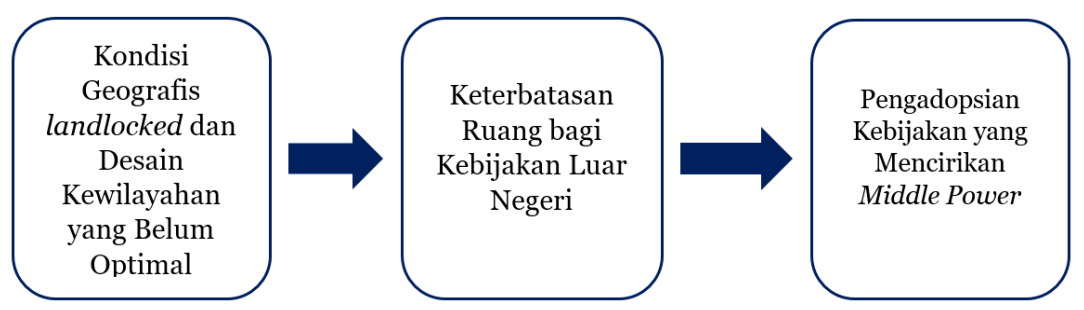

Tulisan ini berangkat dari kurangnya literatur-literatur yang menilik dari perspektif geopolitik dan kewilayahan Kazakhstan serta belum adanya elaborasi mengenai kemungkinan posisi middle power Kazakhstan. Maka dari itu, tulisan ini berusaha untuk mengelaborasi desain kewilayahan Kazakhstan sebagai variabel penjelasan dalam 
menganalisis formasi kebijakan luar negeri Kazakhstan. Dalam menilik kebijakan luar negeri Kazakhstan, hal pertama yang diperhatikan adalah situasi geografisnya sebagai negara yang landlocked. Hal ini menimbulkan implikasi terhadap pola kebijakan luar negeri negara-negara landlocked di Asia Tengah yang meliputi (1) orientasi strategis yang bersifat multi-vektor yang menahan diri untuk bergabung kepada satu aliansi eksklusif dan menjaga kerja sama dengan sistem aliansi yang lain; (2) kebijakan khusus untuk negara-negara transit, termasuk memberikan konsesi dan menjaga hubungan baik serta stabilitas wilayah; dan (3) investasi di bidang infrastruktur yang berkaitan dengan ekspor, terutama energi, karena sangat tergantung dengan pipa minyak (Idan dan Shaffer 2011, 243).

Wilayah Asia Tengah merupakan wilayah negara-negara landlocked yang mengakibatkan negara-negara disana, seperti Kazakhstan, Kyrgyzstan, Tajikistan, Turkmenistan, dan Uzbekistan mengadopsi kebijakan luar negeri yang berbeda dengan negara-negara di wilayah Eropa Tengah dan Timur yang lebih mengarah ke Barat dan berhasil melepaskan diri dari ketergantungan dengan Rusia, sedangkan negara-negara Asia Tengah tidak bisa (Idan dan Shaffer 2011, 244). Hal ini menyebabkan opsi kebijakan luar negeri negara-negara Asia Tengah lebih terbatas. Terlihat dalam hubungan mereka dengan Rusia yang berhasil menjaga instalasi militer di negara-negara Asia Tengah dan penggunaan sarana-sarana ekonomi untuk memaksa negara-negara Asia Tengah mengadopsi keputusan ekonomi dan politik Rusia (Idan dan Shaffer 2011, 244-246).

Tetapi, keterbatasan opsi yang dihadirkan oleh kondisi geografis suatu negara tidak bisa serta-merta diterima sebagai suatu fakta tanpa menganalisis kondisi geografisnya secara lebih mendalam. Pada tahap ini, teori desain kewilayahan dapat diguanakan agar dapat dianalisis lebih lanjut. Para penstudi territorial design ini mengadopsi definisi wilayah sebagai "seperangkat ide spasial, praktek, dan teknologi yang bersama-sama membentuk wilayah" (Branch 2016, 2) dan "seperangkat diskursus kewilayahan yang dominan dan praktek dalam ranah hukum, administratif kebudayaan, dan politik yang bersama-sama menjalin asosiasi antara negara, masyarakat, dan ruang" (Atzili dan Kadercan 2017, 120). Selanjutnya, definisi kewilayahan yang dianut oleh para penstudi territorial design dikonseptualisasikan ke dalam 3 dimensi, yaitu fitur fisik dari ruang, proses demarkasi, dan konstitusi yang ada dalam ruang yang terdemarkasi tersebut (Kadercan 2017, 6). 
Fitur fisik dalam ruang ini merupakan atribut-atribut geografis, termasuk sumber daya demografik dan ekonomi yang ada di dalamnya. Sementara itu, demarkasi merupakan proses kompartementalisasi ruang dan aksi membentuk perbatasan yang perlu agensi manusia dan akhirnya menentukan mode transaksi antara unit-unit politik yang ada, seperti misalnya, negara-negara modern mayoritas mengadopsi proses demarkasi yang menganut prinsip Westphalia, yaitu hard borders yang menentukan model transaksi yang bersifat menghargai kedaulatan dan mengurangi perang antar-negara (Kadercan 2017, 6). Selain itu, aspek konstitutif dari wilayah merujuk pada fungsi sosial dan politik, serta makna yang diberikan terhadap ruang yang terdemarkasi atau dapat disebut sebagai territorialization yang bertujuan untuk meregulasi perilaku masyarakat dan negara dan hubungannya dengan ruang (Kadercan 2017, 6).

Setelah melakukan analisis terhadap tiga dimensi desain kewilayahan ini lalu dapat dilihat sifat pengaruh dari faktor-faktor geografis terhadap keterbatasan opsi kebijakan luar negeri suatu negara. Beberapa penstudi berargumen bahwa pola pikir geopolitik dapat membuat para pembentuk kebijakan menyadari dan mengenali masalah-masalah geografis (Kaplan 2012, 28 dalam Scholvin 2014, 30). Selanjutnya, faktor-faktor geopolitik tidak memengaruhi kebijakan luar negeri secara spesifik, tetapi hanya menyediakan opsi kebijakan yang paling cocok dalam situasi geopolitik sebuah negara (Scholvin 2014, 30). Seperti contoh, Gray (1988, 1991 dalam Scholvin 2014, 30) menghubungkan kebijakan luar negeri dengan faktor-faktor geografis dengan berargumen bahwa geografi menyediakan hambatan dan kesempatan dalam pilihan kebijakan luar negeri suatu negara. Gray (1988, 1991 dalam Scholvin 2014, 31) menyatakan bahwa interaksi antara suatu negara dengan wilayahwilayah dan aspek-aspek geografis di sekitarnya dapat menyediakan pandangan mengenai pilihan kebijakan luar negerinya. Seperti contoh, adanya kedekatan geografis dengan suatu negara berkekuatan besar akan memengaruhi pola konflik, perdagangan, dan kebijakan diplomasi. Hal ini terlihat pada adanya wilayah gurun yang kosong di wilayah utara Kazakhstan yang kemudian dibuat menjadi situs Kosmodrom Baikonur milik Rusia atau adanya kedekatan Korea Selatan dengan Korea Utara sehingga memengaruhi pola diplomasi yang hati-hati (Cohen 2008, 4). 


\section{Desain Kewilayahan Kazakhstan}

Kondisi daratan Asia Tengah yang berbentuk steppe dengan kondisi lingkungan yang keras dan kering menyebabkan komunitaskomunitasetnis pada era sebelum pemerintahan Uni Soviet mengadopsi pola hidup nomadik atau nomadic pastoralism karena dianggap lebih mudah dalam pengaturannya tanpa adanya struktur negara yang terpusat (Schatz 2004, 18). Pada pertengahan abad ke-16, para nomaden mulai dibagi ke dalam tiga pembagian sub-etnis atau umbrella clan yang dalam bahasa Asia Tengah pada waktu itu disebut Zhuz yang meliputi Kishi Zhuz atau Younger Umbrella Clan yang menguasai wilayah sekitar Laut Aral, Laut Kaspia, dan Sungai Ural, Orta Zhuz atau Middle Umbrella Clan yang menduduki wilayah utara dan tengah Kazakhstan, dan Orty Zhuz atau Elder Umbrella Clan yang menduduki wilayah Barat dan Barat Daya (Schatz 2004, 30-31). Pembagian ini diatur menurut tiga zona klimaktik Kazakhstan yang berbeda-beda di setiap wilayah dan untuk memudahkan identifikasi serta pengaturan rute migrasi dan kampkamp di rute-rute migrasi (Schatz 2004, 30).

Dalam aspek kewilayahan dan administrasi, para nomaden ini memiliki peraturan dan perbatasan yang tidak terlalu rigid. Sifat alamiah dataran steppe yang membentang tanpa adanya hambatan dan juga kondisi yang kering membuat perbatasan menjadi kurang relevan. Meskipun begitu, ada beberapa konsepsi perbatasan yang dianut oleh para nomaden di Kazakhstan yang meliputi status keanggotaan dalam klan dan kepemilikan hewan ternak. Konsepsi perbatasan antara komunitas atau "kerajaan" lain di benak para nomaden ini berbeda dengan konsepsi kerajaan-kerajaan Asia Timur dan Eropa yang membedakannya menurut vassal atau wilayah konkrit, tetapi dilakukan melalui keturunan dan pengetahuan akan silsilahnya. Seperti contoh, seorang nomaden yang bertemu dengan nomaden lain yang tidak dikenalnya di dataran steppe akan selalu menanyakan (1) bagaimana kondisi ternakmu? Apakah sehat-sehat saja?; dan (2) dari klan mana engkau berasal? Yang lalu dijawab dengan menceritakan silsilahya sampai tujuh generasi (Schatz 2004, 28). Penekanan bukan pada kewilayahan atau kampung halaman, tetapi kepada afiliasi tribal. Selain itu, satu kelompok keluarga yang saling mengenal biasanya membentuk satu encampment atau aul yang ada saat musim migrasi dan pada saat musim panas, biasanya diadakan festival-festival yang melibatkan aul lainnya, sehingga adanya pertukaran diskursus dan koneksi baru diluar keluarga atau Batasan wilayah (Schatz 24, 28). 
Meskipun begitu, wilayah tetap menjadi sesuatu yang relevan bagi para nomaden, walaupun dalam bentuk yang berbeda. Para nomaden tetap membutuhkan penanda kewilayahan karena sebagian besar para nomaden melakukan migrasi rutin dari wilayah utara menuju ke selatan dan karena para nomaden selalu membawa ternak - yang merupakan harta dan properti yang utama - maka membuat mereka membutuhkan lapangan pastur untuk makanan ternaknya. Sebagai properti utama, hewan ternak milik para nomaden ditandai dengan simbol kelompok atau tamga yang juga digunakan untuk menandai lahan pastur untuk makanan ternak mereka (Schatz 2004, 29). Hal ini menunjukkan bahwa praktek kewilayahan mereka sangat fleksibel dan temporal.

Karakteristik ini mulai berubah pada era Uni Soviet yang menjalankan kebijakan yang bertajuk 'virgin land' yang meliputi kebijakan relokasi dan pembagian wilayah-wilayah menurut etnis, pembentukan pertanian kolektif, dan migrasi orang-orang Rusia secara besar-besaran mengakibatkan komposisi demografi etnis Kazakh sebagai minoritas yang terpecah-pecah di berbagai wilayah dan hilangnya budaya dan gaya hidup nomaden (Schatz 2004, 35 dan 42). Karena adanya kesadaran akan kondisi demografi dan etnis yang terpecah-pecah, maka proses delimitasi dan demarkasi awal Kazakhstan pada tahun 1990-an dengan Rusia dan Tiongkok diwarnai dengan masalah-masalah dan sikap elit-elit Kazakhstan yang tidak terlalu memaksakan adanya keutuhan wilayahnya dengan menawarkan opsi exchange (Karzhaubayeva 2013 dan Ayazbekov 2013, 139).

Hal ini menyebabkan Nazarbayev melakukan kebijakan yang kontradiktif dengan bersiap-siap untuk menjaga integritas wilayah Kazakhstan sembari memperkuat otoritasnya (Smith 2016, 4). Sehingga, pada awal masa-masa kemerdekaan, ide-ide mengenai perbatasan di Kazakhstan memiliki sifat yang kontradiktif, di satu sisi ingin menjaga bentuk perbatasan yang terbuka untuk keperluan perdagangan, jasa-jasa, interaksi sosial, dan movement of people, tetapi, di sisi lain ingin menjaga integritas kewilayahan dan nationhood yang berasal dari alasan-alasan keamanan dan lingkungan ekonomi yang lebih kompetitif (Smith 2016, 3-4). Meskipun begitu, Kazakhstan masih mengusahakan bentuk perbatasan yang lebih terbuka karena pada awalnya, Kazakhstan tidak melihat urgensi untuk membentuk perbatasan yang memiliki keamanan militer dan hal ini ditunjukkan bahwa pada awal sampai pertengahan tahun 1990-an, keamanan perbatasan diisi oleh pasukan-pasukan Rusia. Tetapi, pro- 
posal Nazarbayev mengenai perbatasan yang terbuka tidak digubris oleh Boris Yeltsin. Selain itu, pembentukan kekuatan militer negaranegara Asia Tengah harus dilandasi oleh makna simbolik. Sehingga kemudian, muncul pertanyaan mengenai esensi dari presensi pasukan Kazakstan apabila perbatasannya justru dikontrol oleh pasukan Rusia (Smith 2016, 6).

Hal ini lalu berlanjut pada terbitnya hukum mengenai perbatasan Kazakhstan yang pertama pada November tahun 1992 yang secara umum mendefinisikan perbatasan sebagai hard borders dan dikaitkan dengan kontrol wilayah (Smith 2016, 7). Walaupun begitu, peran CIS sebagai koordinator pembentukan rezim perbatasan antara negara-negara Asia Tengah dan Rusia juga tidak lupa disebut pada artikel 2 (Smith 2016, 7), mengingat pada waktu sebelumnya Kazakhstan berfokus dan sangat aktif dalam pembentukan open borders. Selain itu, ada juga aturan-aturan operasional yang umum dalam pelaksanaan hard borders suatu negara yang meliputi prosedur dokumentasi dan bea cukai, karantina, pengecekan barangbarang yang berkaitan dengan hewan, pengawasan terhadap tumbuhan, dan lain-lain. Aspek hukuman dan keamanan perbatasan pun menjadi terlampau keras, seperti adanya hak bagi aparat keamanan perbatasan untuk menggunakan kekerasan dan senjata yang tidak dibatasi oleh situasi-situasi yang dikecualikan. Selain itu, perbatasan-perbatasan menjadi sasaran sekuritisasi Kazakhstan dengan pembentukan 'border zones' yang membatasi akses terhadap penduduk atau pegawai perbatasan dan juga penggunaan sungai dan tanah agrikultur di sekitarnya (Smith 2016, 8).

Sementara itu, jika dilihat melalui praktek-praktek Kazakhstan yang meliputi administrasi, keamanan, dan pergerakan manusia di perbatasan-perbatasan Kazakhstan, ditemui banyak kasus yang tidak sesuai dengan ide-ide hard borders-perbatasan negara yang dikontrol dan dijaga dengan kuat oleh pemerintah-yang dituangkan dalam hukum perbatasan Kazakhstan pada tahun 1992. Dalam aspek administrasi dan pemerintahan, Kazakhstan mengadopsi pola sentralisasi yang diawali sejak kemerdekaan Kazakhstan pada tahun 1991. Setelah merdeka, Kazakhstan yang baru mendapatkan pelimpahan kekuasaan dari Soviet, berusaha memprioritaskan ekonomi daripada politik, sehingga tidak terlalu memusingkan pola pemerintahan dan tetap mengadopsi sistem pemerintahan Uni Soviet, yaitu administrasi yang terpusat (OECD 2017, 139). Hal ini lalu menciptakan kesenjangan antara administrasi pusat dengan administrasi regional dan lokal yang turut disebabkan oleh struktur 
pendanaan dan fiskal yang buruk. Mode pemerintahan yang topdown membuat administrasi sub-nasional terlalu bergantung kepada pusat dan menyebabkan kurang berkembangnya wilayahwilayah periphery (OECD 2017, 138) yang salah satunya ditandai dengan kepadatan penduduk yang lebih tertuju ke tengah di Astana dan daerah-daerah utara Kazakhstan.

\section{Kebijakan Luar Negeri Kazakhstan dan Posisi Middle Power}

Salah satu hal yang menentukan arah kebijakan luar negeri Kazakhstan adalah kondisi geografisnya. Menurut Nazarbayev, situasi Kazakhstan sebagai negara landlocked memengaruhi kebijakan luar negerinya,

\footnotetext{
"the lack of direct outlet to the open seas and communicative resources makes the republic's participation in international economic relations difficult... For the development of trade and economic relations with other countries and the greater diversification of these relations, it's essential that Kazakhstan secure for itself, in accordance with contemporary law, unimpeded access to the sea. Without the consolidation and specification of this right with neighbors in bilateral treaties and agreements, Kazakhstan will find itself in a dependent position, which could undermine not only its economic, but its political independence" (Nazarbayev 1992 dalam Idan dan Shaffer 2011, 249-250).
}

Sementara itu, Nazarbayev juga menganggap bahwa kondisi geografisnya merupakan keuntungan tersendiri, karena tidak membatasi Kazakhstan untuk mengikuti satu arah saja dan bisa memanfaatkan keuntungan maksimal yang diperoleh dari banyak sisi (Ambrosio dan Lange 2014, 546).

Konsepsi-konsepsi mengenai situasi Kazakhstan membuat kebijakan luar negerinya sebagai refleksi dari posisi geografis negara yang baru merdeka yang menurut interpretasi Kazakhstan, jalur yang paling cocok untuk ditempuh adalah melalui kebijakan luar negeri yang pragmatis, non-konfrontasional dengan berusaha untuk menyeimbangkan hubungan dengan negara-negara berkekuatan besar, serta kebijakan yang aktif di wilayah sekitarnya (Ambrosio dan Lange 2014, 549). Tetapi, karena adanya kedekatan dan konsekuensi yang lebih besar, maka kebijakan 'multi-vektor' Kazakhstan lebih dititikberatkan pada wilayah-wilayah sekitarnya, seperti Asia Tengah, terutama hubungannya dengan Rusia dan Tiongkok (Ambrosio dan Lange 2014, 549). Istilah 'kebijakan luar negeri multi-vektor' pertama 
diterbitkan sebagai diskursus resmi oleh Kementerian Luar Negeri Kazakhstan pada tahun 1995 dalam bentuk brosur yang terdiri dari pidato-pidato dan artikel-artikel yang dipersembahkan Council on the Foreign Policy of Kazakhstan-Pertemuan yang melibatkan pembentuk kebijakan Kazakhstan dari berbagai institusi negara untuk membicarakan strategi kebijakan luar negeri Kazakhstan (Ayazbekov 2014, 109)-pada 15 Februari 1995 (Ayazbekov 2014, 108-109). Dalam brosur tersebut, Menteri Tokaev menjelaskan strategi Kazakhstan "Karena adanya keunikan dalam lokasi geografisnya, Kazakhstan mengadopsi prinsip multivectorism, untuk mewujudkan arah pembangunan kepada hubungan yang seimbang dengan negara-negara Eropa dan Asia” (Ayazbekov 2014, 109).

Selain itu, pada tahun 1992, masalah utama yang dihadapi Kazakhstan adalah mengenai kedaulatan dan integritas kewilayahan, seperti yang diungkapkan oleh Tokaev bahwa "After the collapse of the Soviet Union Kazakhstan faced a difficult dilemma: which foreign policy it needs to pursue in order to better protect its interests? This task was complicated by the peculiar geopolitical location of the young state and uneasy demographics inherited from the times of the colonial past" (Ayazbekov 2014, 115). Sehingga, prioritas Kazakhstan adalah membentuk kebijakan demi mempertahankan perbatasan de facto Kazakhstan pada era Soviet (Ayazbekov 2014, 117) yang akhirnya melahirkan kebijakan yang dijabarkan oleh Tokaev sebagai kebijakan yang berusaha untuk mencapai tingkat kemitraan yang setara antara Rusia dan Tiongkok yang dapat meminimalisasi keburukan dari kedua negara tersebut, sehingga dapat menjaga kedaulatan dan keamanan Kazakhstan (Ayazbekov 2014, 121). Hal ini menyebabkan kebijakan luar negeri Kazakhstan pada masa awal-awal kemerdekaan dipenuhi kekhawatiran akan adanya serangan dari negara-negara tetangga yang tidak lain tidak bukan adalah Rusia dan Tiongkok, sehingga merupakan dua negara terpenting dalam kebijakan luar negeri Kazakhstan (Ayazbekov 2014, 116).

Selain itu, kekhawatiran Kazakhstan tidak hanya terletak pada Rusia dan Tiongkok, tetapi keamanan regional Asia Tengah yang berusaha dicegah untuk masuk ke dalam konflik 'Great Game' seperti dalam pidato Nazarbayev pada tahun 1997 yang "Involve the country in an unpredictable vortex of various regional conflicts of military, political, economic, and confessional nature" (Ambrosio dan Lange 2014, 551). 'Great Game' sendiri adalah sebutan untuk wilayah Asia Tengah yang mengalami perebutan pengaruh oleh negara-negara 
berkekuatan besar. Istilah ini disematkan pada era kolonial saat Inggris dan Rusia berebut pengaruh di Asia Tengah. Kazakhstan menganggap bahwa kedaulatan negaranya akan terjaga jika wilayah Asia Tengah juga terjaga keamanannya, sehingga, prioritas kebijakan luar negeri setelah Rusia dan Tiongkok, adalah negara-negara di wilayah Asia Tengah yang disebut sebagai 'Saudara yang dibesarkan oleh satu ibu' (Ambrosio dan Lange 2014, 550). Prioritas ketiga adalah negara-negara yang berada di luar wilayah terdekatnya, seperti AS, Uni Eropa, Turki, dan lainnya, yang berperan sebagai hedge atas dominasi Rusia dan merasa bahwa kebijakan luar negeri 'multi-vektor'-nya dapat bekerja dengan baik jika Kazakhstan memiliki kedaulatan dan pengaruh di dunia internasional (Ambrosio dan Lange 2014, 551).

Gabungan ruang lingkup kebijakan luar negeri Kazakhstan ini membuat Nazarbayev memformulasikan dua peran penting Kazakhstan, yaitu (1) Kazakhstan harus bertindak sebagai anggota komunitas internasional yang bertanggung jawab; dan (2) memiliki tanggung jawab untuk mengedepankan stabilitas geopolitik dan keamanan regional; Sehingga, Kazakhstan berusaha untuk menjadi jembatan dan membangun relasi yang damai dengan beberapa aktor sekaligus (Ambrosio dan Lange 2014, 551). Formulasi kebijakan luar negeri Kazakhstan dilandasi oleh kesadaran akan adanya keterbatasan kapabilitas dan geografis, sehingga, seperti yang akan dijabarkan pada sub-bab-sub-bab selanjutnya, cenderung berusaha untuk bertindak seaktif mungkin dalam dunia internasional, seperti layaknya negara-negara middle power yang membuatnya tidak terhindar dari kontradiksi.

\section{Kesimpulan}

Penulis memiliki kesimpulan bahwa Kazakhstan strategi hedging Kazakhstan dipengaruhi oleh posisi kewilayahan Kazakhstan yang landlocked dan 'terisolasi' dari wilayah-wilayah yang strategis di Asia Tengah. Desain kewilayahan Kazakhstan terbagi menjadi tiga fase dan bentuk, yaitu (1) abad ke-16-19 pada saat Kazakhstan merupakan wilayah tanpa batasan yang jelas dan berisi oleh penduduk yang nomadik, sehingga mengadopsi bentuk perbatasan yang soft; (2) masa Uni Soviet yang membagi wilayah Asia Tengah menjadi Soviet Socialist Republic yang membuat Kazakh SSR mengadopsi bentuk konstitutif yang heterogen dan bentuk perbatasan yang hard; dan (3) masa setelah kemerdekaan dengan Kazakhstan mengadopsi perbatasan yang hard dan dimensi konstitutif yang heterogen, sehingga kontradiktif. Hal ini lalu berdampak pada 
kesadaran Kazakhstan akan kelemahan wilayahnya yang membuatnya pro-aktif di menjalin hubungan dengan Rusia dan Tiongkok pada masa-masa awal kemerdekaannya dan membentuk kebijakan luar negeri sebagai middle power.

Variabel pertama, desain kewilayahan menjadi salah satu faktor pengaruh dalam strategi hedging Kazakhstan terhadap Rusia dan Tiongkok karena posisi Kazakhstan yang berada ditengah-tengah kedua negara tersebut mengharuskannya untuk mengutamakan penyelesaian masalah perbatasan dengan kedua negara tersebut. Tetapi, ternyata pemerintahan Kazakhstan yang sentral dan wilayahnya yang terlalu luas membuatnya tidak bisa menjaga perbatasan dengan maksimal. Hal ini lalu membuat variabel kedua memengaruhi strategi hedging melalui konsepsi kebijakan luar negeri dan implementasi-nya yang memiliki kecenderungan sebagai negara middle power. Kazakhstan menyadari kelemahan wilayahnya dan kapabilitasnya sebagai negara yang baru merdeka, tetapi mereka memilih untuk menjadi pro-aktif dan berperan sebagai negara yang matang dalam dunia internasional. Kontradiksi antara kurangnya kapabilitas material Kazakhstan dengan keinginannya untuk menjaga independensi-nya dari intervensi negara-negara berkekuatan besar, membuatnya memilih strategi hedging yang kontradiktif dan berusaha untuk menyeimbangkan kebijakannya yang menjalin hubungan dekat dengan semua pihak, tetapi yang ditujukan justru untuk menjaga independensi dari ketergantungan akan norma-norma dan aliansi-aliansi dengan negara-negara berkekuatan besar. 


\section{Daftar Pustaka}

\section{Buku atau Artikel dalam Buku}

Schatz, Edward, 2004. Modern Clan Politics: The Power of "Blood" in Kazakhstan and Beyond. Seattle: University of Washington Press.

\section{Artikel Jurnal}

Ambrosio, Thomas dan William A. Lange, 2014. "Mapping Kazakhstan's Geopolitical Code: An Analysis of Nazarbayev's Presidential Addresses, 1997-2014", Eurasian Geography and Economics, 55 (5): 537-559.

Atzili, Boaz dan Burak Kadercan, 2017. "Territorial Designs and International Politics:TheDiverging Constitution ofSpaceand Boundaries", Territory, Politics, Governance, 5 (2): 115-130.

Branch, Jordan, 2016. "Territory as an Institution: Spatial Ideas, Practices, and Technologies", Territory, Politics, and Governance, 5 (2): 131-144.

Cheng-Chwee, Kuik, 2008. "The Essence of Hedging: Malaysia and Singapore's Response to a Rising China”, Contemporary Southeast Asia: A Journal of International and Strategic Affairs, 30 (2): 159-185.

Hanks, Reuel R., 2009. "'Multi-Vector Politics' and Kazakhstan's Emerging Role as a Geo-Strategic Player in Central Asia", Journal of Balkan and Near Eastern Studies, 11 (3): 257-267.

Idan, Avinoam dan Brenda Shaffer, 2011. "The Foreign Policies of Post-Soviet Landlocked States”, Post-Soviet Affairs, 27 (3): 241-268.

Kadercan, Burak, 2017. "Territorial Design and Grand Strategy in the Ottoman Empire", Territory, Politics, Governance, 5 (2): 158-176.

Scholvin, Soren dan Mikael Wigell, 2018. "Power Politics by Economic Means: Geoeconomics as an Analytical Approach and Foreign Policy Practice”, Comparative Strategy, 37 (1): 7384 . 
Smith, Jeremy, 2016. "The Transformation of Soviet Republic Borders to International Borders: Competing Concepts of the Kazakhstan-Russia Border", Journal of Borderlands Studies, 32 (1): 91-104.

Vinokurov, E., 2017. "Eurasian Economic Union: Current State and Preliminary Results", Russian Journal of Economics, 3 (1): 54-70.

Weitz, Richard, 2006. "Averting a New Great Game in Central Asia", The Washington Quarterly, 29 (3): 155-167.

\section{Laporan Penelitian dan Tesis}

Ayazbekov, Anuar, 2014. Independent Kazakhstan and the 'Black Box' of Decision-Making: Understanding Kazakhstan's Foreign Policy in the Early Independence Period (1991-4). Disertasi. St Andrews: University of St Andrews.

Karzhaubayeva, Ainur, 2013. Frontier Migration between Kazakhstan and Russia: The Case of the West Kazakhstan. Disertasi Doktoral. Praha: Faculty of Science, Department of Demography and Geodemography, Charles University.

OECD, 2017. OECD Territorial Reviews: Kazakhstan. Paris: OECD Publishing.

Peyrouse, Sebastien, 2012. "Central Asia's Long-Term Questions Remain Unanswered After the Shanghai Cooperation Organization Summit", Foreign Policy and Civil Society Program on Wider Europe, The German Marshall Fund of the United States.

Sultangaliyeva, Alma, 2016. "Kazakhstan and its Negihbors: Opportunity and Limitation". Working Paper. The Institute of World Economics and Politics under the Foundation of the President of Kazakhstan Leader of the Nation.

\section{Publikasi Daring}

China International Water Law Programme, t.t. "Sino-Kazakhstan Joint Declaration on Further Deepening Comprehensive 
Strategic Partnership" [daring]. Tersedia dalam https:// www.internationalwaterlaw.org/documents/regionaldocs/ China-Kazakhstan_declaration_7_Sept_2013-CIWL unofficial_translation.pdf [diakses pada 8 September 2018].

Collective Security Treaty Organization, 2002. "Charter of the Collective Security Treaty Organization" [daring]. Tersedia dalam http://www.odkb-csto.org/documents/detail. php?ELEMENT_ID=1896 [diakses pada 21 September 2018].

Kamalova, Gyuzel, 2014. "Nazarbayev Calls to Solve Boarder Security Issues at SCO", Tengrinews [daring]. Tersedia dalam https://en.tengrinews.kz/politics_sub/Nazarbayevcalls-to-solve-boarder-security-issues-at-SCO-256112/ [diakses pada 5 September 2018].

Kazpravda, 2015. "Kazakhstan Reminds the SCO About the Water Scarcity Problem" [daring]. Tersedia dalam https://www.kazpravda.kz/en/news/politics/kazakhstan-reminds-the-sco-about-the-water-scarcity-problem/ [diakses pada 5 September 2018].

OEC, t.t. "What Does Russia Export to Kazakhstan? (2016)", the Observatory of Economic Complexity [daring]. Tersedia dalam https://atlas.media.mit.edu/en/visualize/tree_map/hs92/ export/rus/kaz/show/2016/ [diakses pada 15 September 2018].

Peyrouse, Sebastien, 2008. "Sino-Kazakh Relations: A Nascent Strategic Partnership”, Jamestown [daring]. Tersedia dalam https://jamestown.org/program/sino-kazakh-relations-anascent-strategic-partnership/ [diakses pada 8 September 2018].

Shodganga t.t. Negotiations and Settlements of Border Disputes [online]. dalam http://shodhganga.inflibnet.ac.in/bitstream/10603/119862/9/o9_chapter\%203.pdf [diakses pada 12 September 2018]. 